\title{
The Impact of Attractiveness on Retail Managers' Decisions: Labor Market Discrimination When Hiring Salespeople
}

\author{
Zeev Shtudiner \\ Department of Economics and Business Administration, Ariel University, Ariel, Israel \\ Email: zeevs@ariel.ac.il
}

How to cite this paper: Shtudiner, Z. (2019) The Impact of Attractiveness on Retail Managers' Decisions: Labor Market Discrimination When Hiring Salespeople. Modern Economy, 10, 2253-2263.

https://doi.org/10.4236/me.2019.1011141

Received: October 4, 2019

Accepted: November 18, 2019

Published: November 21, 2019

Copyright $\odot 2019$ by author(s) and Scientific Research Publishing Inc. This work is licensed under the Creative Commons Attribution International License (CC BY 4.0).

http://creativecommons.org/licenses/by/4.0/

\section{c) (i) Open Access}

\begin{abstract}
This paper investigates the role of physical attractiveness in retail managers' decisions about hiring salespeople. Using data on attractiveness and the potential employment qualifications of 30 candidates, we found that retail managers prefer to hire candidates who are more physically attractive. This beauty premium can be explained by our findings on the positive correlation between candidates' attractiveness and the perceived presence of traits essential for becoming a successful salesperson, such as charisma, kindness and persuasiveness. We also found that beauty plays a more important role for female candidates, from the earliest stage of the hiring process. No difference was found between the beauty premiums in the decisions of male and female retail managers. When this study's results are coupled with results from previous studies demonstrating that an employee's attractiveness has been found to influence both performance and behaviors of customers and managers, the managerial relevance of the attractiveness effect becomes apparent. Based on our findings, we recommend that retail managers remain vigilant about the potential for intentional or unintentional biases based on physical appearance when hiring employees.
\end{abstract}

\section{Keywords}

Beauty, Labor Market, Discrimination, Salespeople

\section{Introduction}

Cultural and social changes in recent years, particularly social media and networking, have been accompanied by ever-more importance being placed on external appearance. This trend is present in different cultures and societies, and 
has also led to academic studies on the influence of physical appearance. Previous research has found that the appearance influences the labor market in several ways: attractive workers receive higher pay [1] [2], are more likely to be hired [3] [4], and have more diverse career choices [5].

Increasing competitiveness in some industries has caused retail managers who consider candidates for employment to pay more attention to personal traits, such as appearance, in an attempt to gain or maintain their competitive edge [6]. To further analyze this process, we designed a two-stage study to test the role of physical attractiveness in the hiring process used by managers of retail stores. In the first stage, students from several universities in Israel were asked to rate photographed persons for their attractiveness and six essential traits (charisma, kindness, persuasiveness, human relations, work ethic, professionalism) for a salesperson [7] [8]. In the second stage, we showed the photos to retail managers and asked them to rate their interest in hiring each candidate. Our results indicate that more attractive candidates are more likely to be offered a job. This beauty premium exists regardless of the manager's gender and is significantly greater for female candidates than for male candidates. Our results also indicate that attractive people are believed to possess the six desirable traits of successful salespeople.

This study makes several contributions to the existing literature on the beauty premium in the labor market. First, previous research discussed the impact of physical appearance on the performance of salespeople, and we focus on hiring decisions. Second, our population of subjects is unique, and includes retail managers, who are the ones who actually make decisions about hiring new employees, rather than the students often surveyed. Third, we provide evidence for a positive correlation between physical attractiveness and viewers' attribution of traits that are desirable for a successful salesperson. It appears that retail managers make inferences towards salespeople's traits based on their physical attractiveness, and these inferences affect their attitudes. This finding is consistent with the large body of literature in psychology that shows that individuals attribute a broad range of positive characteristics and dispositions to attractive men and women (e.g. [9]).

The remainder of the paper is organized as follows. Section 2 reviews relevant prior studies that form the foundation for our hypotheses. These hypotheses are presented in Section 3, while Section 4 presents the methodology for both parts of the study: the image-rating questionnaire and the employment questionnaire for retail managers. The results of the study are found in Section 5 , and the conclusions in Section 6.

\section{Literature Review}

\subsection{The Effect of Physical Appearance on Perceptions and Judgements}

The issue under consideration is deftly encapsulated in the title of a pioneering 
article [5]. "What is beautiful is good", expresses the prevalent belief that attractive people also have desirable social features such as sensitivity, pleasantness, modesty, openness, and balance. This bias is due to the halo effect, which contends that judgments concerning unknown attributes are influenced by a general impression [10]. Specifically, when people meet an attractive person, they assume that the person also has positive personality traits. A fundamental principle of human perception is that people form their first impression of others based on immediately observable characteristics, especially physical appearance [11]. The face is exposed to public view and is key to human identity, so the perception of another person's physical attractiveness is strongly influenced by facial appearance [12].

Studies on the effect of external appearance on judgment and perception demonstrate that jurors' tend to favor more attractive litigants [13], greater tolerance is shown for work that violates ethical standards when it was done by accountants who are considered more attractive [14], attractive people are thought not only more socially and intellectually competent than their less attractive peers [15], but also better informed and more decisive, motivated and logical $[16]$.

\subsection{Beauty Premium in the Labor Market}

Reference [17] was the first to suggest that better-looking people earn more than average-looking people across occupations in the labor market. More recently, [18] and [3] conducted field experiments that improved our understanding of the beauty premium. One study [18] investigated the performance of good-looking candidates in the hiring process by applying for 2656 jobs advertised in Israel. More than 5000 resumes were submitted in pairs, one without a photograph and one, otherwise-identical, with a photo. This study found that attractive male candidates are significantly more likely to be invited for an interview than either plain males or those who did not send a photograph. Perhaps surprisingly, they found that attractive female candidates are significantly less likely to be invited to interview (18\% less than ordinary-looking female candidates and $22.5 \%$ less than female candidates without photos). According to the authors, a substantial part of this gap can be attributed to female jealousy and envy (noting that $93 \%$ of the respondents in their sample were female). In study [3], researchers digitally manipulated 50 genuine photographs of men and women so they would match (attractive) or deviate from (unattractive) the two golden ratios of facial proportions documented in [19]. They found that attractive people receive $36 \%$ more callbacks than others.

Regarding the effect of appearance on hiring employment potential, [11] asked 180 psychology students to imagine that they were working in human resources, and needed to decide whether or not to interview candidates, of varying quality, who had responded to a fictitious ad. Participants were divided randomly and those in the control group received resumes without any image. The 
results showed that appearance was not a factor for high-quality resumes, but was important when the resume was mediocre. When the resume was average, external attractiveness was preferred over a resume without a photograph. The authors concluded that attractiveness can be advantageous for candidates with lower quality resumes.

Reference [20] investigated the role of physical attractiveness when judging the severity of unethical workplace behavior. They found that dubious or "grey" behavior of attractive employees was evaluated less severely that of plain-looking employees, which confirms the halo effect. Women have been found [21] to value attractiveness more than men when making decisions related to the labor market.

\subsection{The Impact of the Attractiveness in Marketing}

There is evidence that physically-attractive salespeople perform better than their otherwise equivalent but unattractive counterparts [22]. When soliciting small donations, attractive solicitors received nearly twice the donations as their unattractive counterparts. Moreover, customers are less cordial to unattractive salespeople and less likely to comply with their requests, than they are if the salesperson is attractive. As [23] found, this also applies to recorded, video presentations. The presentation they studied concerned purchasing automobile insurance, and was received more favorably when the presenter was attractive.

In a related area, several studies showed the greater effectiveness of physically attractive spokespeople for changing opinions and evaluating products [24] [25]. A message presented by a physically attractive person can be more persuasive than a similar message delivered by a less attractive spokesperson [26]. Attractiveness in advertising can create changes in attitudes and purchase plans [27].

Although most prior studies on marketing support the presence of a beauty premium for salespeople's performance, some results have been mixed. For example, [28] did not find evidence to support the influence of physical attractiveness on advertising results for grocery products (soft drinks and cheeses). Reference [29] assessed the impact of attractive male and female models on subjects' evaluations of ads, with contradictory findings. They concluded that the impact of physical attractiveness may be connected to the subject or type of product, the viewer's gender, and spokesperson's gender.

\section{Hypotheses}

Based on the current literature on the subject, we developed the following hypotheses:

1) There will be a positive correlation between candidate's attractiveness and perceptions of the essential traits for being a successful salesperson: charisma, kindness, persuasiveness, human relations, work ethic, professionalism (references [5] and [9]).

2) Managers will show greater willingness to hire attractive candidates than 
plain-looking candidates (references [17] and [18]).

3) The beauty premium will be higher for female candidates than for men (reference [22]).

4) The beauty premium will be higher in the decisions of female retail managers than male retail managers' decisions (reference [22]).

\section{Methodology}

\subsection{Ratings of Candidates' Traits}

This study focuses on the facial attractiveness of candidates for positions as retail salespeople. We chose 30 headshots of 15 real men and 15 real women from the site http://www.faceresearch.org. All headshots were of Caucasian young adults. We showed the photographs to 150 students at universities in Israel (78 women, 72 men; mean age, 24.5 , s.d. for age, 3.3). They were asked to rate the photos, on scale of 1 to 9 , for attractiveness and six traits considered essential for salespeople. The photos were anonymous, and no identifying information was displayed. Each subject rated five photos of men and five of women, and each photo appeared in more than one version of the questionnaire.

Despite our focus on attractiveness, the students were also asked to assess the ethnicity of the person in the photograph. Ethnicity evaluations are important because considerable evidence has exposed discrimination against Jews of North African and Middle Eastern ("Sephardi") origin compared with Jews of European (Ashkenazi) origin in Israel (see [30] [31]).

\subsection{Ratings of Tendency to Employ}

To test for the role of physical attractiveness in the hiring process, we showed the 30 photos rated in the first stage, above, to 50 store managers ( $48 \%$ male and $52 \%$ female) who work in two large shopping malls in Israel. They were asked to assume that the photos belonged to candidates for employment as a salesperson in their store, and that all of the candidates meet the requirements for the job. The managers were asked to rate their interest in hiring each candidate on a $\mathrm{Li}$ kert scale ranging from 1 (unlikely to hire) to 9 (likely to hire). The average number of employees in each shop was 6.5 (s.d. 3.9).

\section{Results}

\subsection{Correlations between Attractiveness and Other Traits}

We began by asking if, when subjects rate photographs, there are positive correlations between attractiveness and other traits essential for success as a salesperson? We calculated these correlations for all of the photos, for photos of males and females separately, and also by gender of the viewer. The results are displayed in Table 1 . We find that all the correlations are positive and significantly higher than zero. This result consistent with a vast psychological literature shows that individuals attribute a wide array of positive characteristics and dispositions to attractive men and women (see [9] for a review). 


\subsection{Likelihood to be Hired and Attractiveness}

We then estimated the effect of a candidate's attractiveness on the likelihood he or she would be hired. Figure 1 displays the average attractiveness of each candidate and the average willingness to employ him or her. Each point represents a candidate $(\mathrm{n}=30)$, with male candidates (light dotted line) and female candidates (black dotted lines) displayed separately. Both trend lines show a positive correlation between attractiveness and the likelihood of being offered a job. As apparent in Figure 1, the trend line for female candidates is steeper, which means that attractiveness plays a more significant role for female candidates than male candidates.

In order to control for additional explanatory variables, OLS regressions were calculated, with the dependent variable Would You Hire ${ }_{i j}$, which represents the interest of manager $j$ in hiring candidate $i$ on a scale ranging from 1 to 9 . The main independent variable is Attractive $_{\mathrm{i}}$, (average ratings on a scale of 1 to 9, where an attractive (unattractive) candidate $i$ will get the value of $9(1)$ ). Since

Table 1. Correlations between attractiveness and other perceived traits.

\begin{tabular}{ccccccc}
\hline & \multicolumn{5}{c}{ Perceived Traits } \\
\cline { 2 - 7 } & $\begin{array}{c}\text { Work } \\
\text { Ethic }\end{array}$ & Persuasiveness & Charisma Professionalism Kindness $\begin{array}{c}\text { Human } \\
\text { Relations }\end{array}$ \\
\hline All Data & $0.25^{* * *}$ & $0.61^{* * *}$ & $0.66^{* * *}$ & $0.33^{* * *}$ & $0.38^{* * *}$ & $0.50^{* * *}$ \\
Male-to-Male & $0.26^{* * *}$ & $0.60^{* * *}$ & $0.64^{* * *}$ & $0.21^{* * *}$ & $0.37^{* * *}$ & $0.55^{* * *}$ \\
Male-to-Female & $0.30^{* * *}$ & $0.45^{* * *}$ & $0.52^{* * *}$ & $0.38^{* * *}$ & $0.35^{* * *}$ & $0.46^{* * *}$ \\
Female-to-Male & $0.14^{* * *}$ & $0.61^{* * *}$ & $0.71^{* * *}$ & $0.22^{* * *}$ & $0.33^{* * *}$ & $0.47^{* * *}$ \\
Female-to-Female & $0.37^{* * *}$ & $0.69^{* * *}$ & $0.67^{* * *}$ & $0.46^{* * *}$ & $0.44^{* * *}$ & $0.52^{* * *}$
\end{tabular}

Notes: The male-to-male (female-to-male) group includes male (female) subjects ranking only male photos. The male-to-female (female-to-female) group includes male (female) subjects ranking only female photos. ${ }^{* * *} \mathrm{p}<0.01,{ }^{* *} \mathrm{p}<0.05,{ }^{*} \mathrm{p}<0.1$.

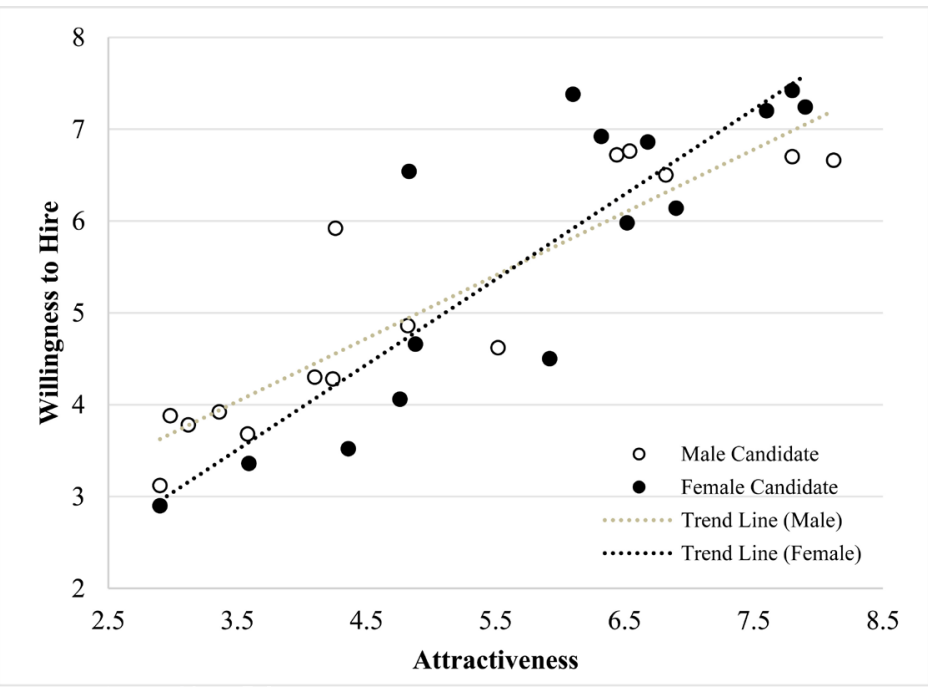

Figure 1. Willingness to hire and attractiveness. 
the managers were observed at several points and rank several candidates, clustering is an appropriate method [32]. The standard errors in parentheses are robust to heteroscedasticity, and corrected for possible non-independence of observations by clustering for each manager. The results of the regression analysis are displayed in Model 1 (Table 2). The following control variables were added in Model 2: Candidate Ethnicity ${ }_{\mathrm{i}}$ is the average rating of ethnic origin of the candidate, on a scale of 1 to 9 (where 1 equals "definitely Sephardi," 9 equals "definitely Ashkenazi," and 5 is "uncertain"). Manager Male ${ }_{j}$ is a dummy variable that gets a value of 1 if manager $j$ is male; otherwise, it is 0. Age $_{j}$ is the manager's age, Number of Employees $s_{j}$ is the number of employees in the store managed by $j$. The coefficient of the variable Attractiveness is positive and significant (1\%) both with (0.78) and without (0.77) controls, meaning that a more attractive candidate has a higher chance of being hired.

To compare the decisions regarding male and female candidates, and consider

Table 2. The effect of attractiveness on the tendency to hire a candidate (on a scale of 1 - 9).

\begin{tabular}{|c|c|c|c|c|c|}
\hline & \multicolumn{5}{|c|}{ Models } \\
\hline & (1) & (2) & (3) & $(4)$ & (5) \\
\hline \multirow[t]{2}{*}{ Constant } & $1.126^{* * *}$ & $0.993^{* * *}$ & 1.208 & 0.433 & 0.155 \\
\hline & $(0.419)$ & $(0.669)$ & $(0.862)$ & $(0.602)$ & $(0.648)$ \\
\hline \multirow{2}{*}{ Attractive } & $0.781^{\star * *}$ & $0.768^{\star * *}$ & $0.673^{* * *}$ & $0.915^{* * *}$ & $0.915^{\star * *}$ \\
\hline & $(0.066)$ & $(0.070)$ & $(0.080)$ & $(0.070)$ & $(0.070)$ \\
\hline \multirow[t]{2}{*}{ Candidate Ethnicity } & & 0.019 & 0.015 & 0.022 & 0.018 \\
\hline & & $(0.154)$ & $(0.012)$ & $(0.012)$ & $(0.015)$ \\
\hline \multirow[t]{2}{*}{ Manager Male } & & 0.287 & 0.460 & 0.111 & 0.285 \\
\hline & & $(0.221)$ & $(0.292)$ & $(0.184)$ & $(0.220)$ \\
\hline \multirow[t]{2}{*}{ Age } & & 0.008 & 0.015 & 0.006 & 0.008 \\
\hline & & $(0.017)$ & $(0.024)$ & $(0.014)$ & $(0.017)$ \\
\hline \multirow[t]{2}{*}{ Number of Employees } & & -0.029 & -0.030 & -0.024 & -0.028 \\
\hline & & $(0.017)$ & $(0.025)$ & $(0.022)$ & $(0.017)$ \\
\hline \multirow[t]{2}{*}{ Candidate Male } & & & & & $1.332^{* * *}$ \\
\hline & & & & & $(0.322)$ \\
\hline \multirow[t]{2}{*}{ Att. ${ }^{*}$ Candidate Male } & & & & & $-0.243^{* * *}$ \\
\hline & & & & & $(0.058)$ \\
\hline Observations & 1500 & 1500 & 750 & 750 & 1500 \\
\hline R-Squared & 0.271 & 0.272 & 0.257 & 0.280 & 0.275 \\
\hline Manager & All & All & All & All & All \\
\hline Candidate & All & All & Male & Female & All \\
\hline Controls & $\mathrm{N}$ & $\mathrm{Y}$ & $\mathrm{Y}$ & $\mathrm{Y}$ & $\mathrm{Y}$ \\
\hline
\end{tabular}

Note: Clustered standard errors (by manager) are presented in parentheses. ${ }^{*}, * *,{ }^{* *}$ denote significance at the $10 \%, 5 \%$, and $1 \%$ levels respectively. 
if the beauty premium in the hiring process is different for male and female candidates, we re-calculated Model 2 separately for photos of men (Model 3) and photos of women (Model 4). The coefficients of the attractiveness variable in both regressions are positive and significant. The coefficient is higher for female candidates (0.92) than for male candidates (0.67). In order to determine if this difference is significant, we ran an additional regression (Model 5) with an interaction variable between the variables of Attractiveness and Candidate Male (dummy variable $=1$ if the candidate is male; otherwise $=0$ ). Since the coefficient of the interaction variable is negative and significant we can conclude that the beauty premium for female candidates is significantly higher than that for males.

We further asked if female and male managers weigh attractiveness differently during the hiring process, and analyzed the effect of the manager's gender on the beauty premium by calculating regressions for male managers and female managers separately. Table 3 presents the results of these regressions, in which the

Table 3. The effect of the manager's gender on the beauty premium.

\begin{tabular}{|c|c|c|c|}
\hline & \multicolumn{3}{|c|}{ Models } \\
\hline & (1) & (2) & (3) \\
\hline \multirow[t]{2}{*}{ Constant } & 0.171 & $1.700^{\star *}$ & 1.171 \\
\hline & $(1.129)$ & $(0.792)$ & $(0.766)$ \\
\hline \multirow[t]{2}{*}{ Attractive } & $0.829^{* * *}$ & $0.720^{* * *}$ & $0.732^{* * *}$ \\
\hline & $(0.105)$ & $(0.091)$ & $(0.091)$ \\
\hline \multirow[t]{2}{*}{ Candidate Ethnicity } & 0.101 & -0.001 & 0.019 \\
\hline & $(0.237)$ & $(0.227)$ & $(0.155)$ \\
\hline \multirow[t]{2}{*}{ Candidate Male } & 0.259 & -0.165 & 0.031 \\
\hline & $(0.150)$ & $(0.110)$ & $(0.098)$ \\
\hline \multirow[t]{2}{*}{ Age } & 0.027 & -0.002 & 0.008 \\
\hline & $(0.034)$ & $(0.020)$ & $(0.017)$ \\
\hline \multirow[t]{2}{*}{ Number of Employees } & -0.021 & -0.034 & -0.028 \\
\hline & $(0.024)$ & $(0.029)$ & $(0.017)$ \\
\hline \multirow[t]{2}{*}{ Manager Male } & & & -0.149 \\
\hline & & & $(0.895)$ \\
\hline \multirow[t]{2}{*}{ Att. ${ }^{\star}$ Manager Male } & & & -0.082 \\
\hline & & & $(0.138)$ \\
\hline Observations & 720 & 780 & 1500 \\
\hline R-Squared & 0.265 & 0.257 & 0.269 \\
\hline Manager & Male & Female & All \\
\hline Candidate & All & All & All \\
\hline Controls & $\mathrm{Y}$ & $\mathrm{Y}$ & $\mathrm{Y}$ \\
\hline
\end{tabular}

Note: Clustered standard errors (by manager) are presented in parentheses. ${ }^{*},{ }^{* *},{ }^{* *}$ denote significance at the $10 \%, 5 \%$, and $1 \%$ levels respectively 
dependent variable is Would You Hire $\mathrm{i}_{\mathrm{ij}}$, measured on a scale from 1 - 9. The main independent variable is Attractive $e_{\mathrm{i}}$ (with 9 representing the most attractive and 1, the least). Regressions for male managers are in column 1; and female managers, in column 2. The third regression includes an interaction variable, and is shown in column 3. Columns 1 and 2 in Table 3 show that attractive candidates are more likely to get hired, both when the manager is male (the coefficient of Attractive is 0.829 ) and when the manager is female (0.720). The interaction coefficient is not significant, implying that the beauty premium plays the same role in the decisions of male and female managers.

\section{Conclusions}

We found that attractive people are believed to possess traits that are desirable for being a successful salesperson. This result is consistent with the halo effect, by which attitudes regarding unknown attributes are influenced by general impressions. Indeed, we found that attractive candidates have a greater chance of being accepted for employment as salespeople. This result shows that discrimination based on attractiveness occurs not only in wage determination or promotion decisions but also in the earliest stage of the hiring process. Previous research has shown that the performance of more attractive employees in the field of marketing is higher than that of plain-looking employees. Our research adds that managers recognize the functional role of physical appearance, and prefer to hire attractive salespeople.

We also found that the beauty premium for female candidates is significantly higher than that for males, consistent with the prevailing view that physical appearance plays a more important role for women. Our survey design and sample allowed us to compare the decisions of male and female managers, and analyze if they assign different weights for attractiveness in the hiring process. We did not find evidence for such a difference, and conclude that both male managers and female managers prefer to hire attractive salespeople. Moreover, the beauty premium plays the same role in their decisions. Although previous research has shown that attractiveness has a positive impact on employee performance in marketing, we recommend that retail managers remain vigilant and aware of intentional or unintentional biases based on physical appearance when hiring employees, regardless of their other qualifications, because bias could eliminate suitably qualified candidates early in the selection process.

We did not find the expected gender differences in the importance of attractiveness. Perhaps we could not detect them because the number of observations was too small. To analyze these differences, a larger number of observations should be collected in future research.

\section{Conflicts of Interest}

The authors declare no conflicts of interest regarding the publication of this paper. 


\section{References}

[1] Andreoni, J. and Petrie, R. (2008) Beauty, Gender and Stereotypes: Evidence from Laboratory Experiments. Journal of Economic Psychology, 29, 73-93. https://doi.org/10.1016/j.joep.2007.07.008

[2] Parrett, M. (2015) Beauty and the Feast: Examining the Effect of Beauty on Earnings using Restaurant Tipping Data. Journal of Economic Psychology, 49, 34-46. https://doi.org/10.1016/j.joep.2015.04.002

[3] Bóo, F.L., Rossi, M.A. and Urzúa, S.S. (2013) The Labor Market Return to an Attractive Face: Evidence from a Field Experiment. Economics Letters, 118, 170-172. https://doi.org/10.1016/j.econlet.2012.10.016

[4] Shapir, O. and Shtudiner, Z. (2015) Beauty Is in the Eye of the Employer: Labor Market Discrimination of Accountants. https://doi.org/10.2139/ssrn.2655407

[5] Dion, K., Berscheid, E. and Walster, E. (1972) What Is Beautiful Is Good. Journal of Personality and Social Psychology, 24, 285. https://doi.org/10.1037/h0033731

[6] Ahearne, M., Gruen, T.W. and Jarvis, C.B. (1999) If Looks Could Sell: Moderation and Mediation of the Attractiveness Effect on Salesperson Performance. International Journal of Research in Marketing, 16, 269-284. https://doi.org/10.1016/S0167-8116(99)00014-2

[7] Dodge, A.F. (1938) Social Dominance and Sales Personality. Journal of Applied Psychology, 22, 132. https://doi.org/10.1037/h0055583

[8] Warr, P., Bartram, D. and Martin, T. (2005) Personality and Sales Performance: Situational Variation and Interactions between Traits. International Journal of Selection and Assessment, 13, 87-91. https://doi.org/10.1111/j.0965-075X.2005.00302.x

[9] Feingold, A. (1992) Good-Looking People Are Not What We Think. Psychological Bulletin, 111, 304-341. https://doi.org/10.1037/0033-2909.111.2.304

[10] Nisbett, R.E. and Wilson, T.D. (1977) Telling More than We Can Know: Verbal Reports on Mental Processes. Psychological Review, 84, 231. https://doi.org/10.1037//0033-295X.84.3.231

[11] Watkins, L.M. and Johnston, L. (2000) Screening Job Applicants: The Impact of Physical Attractiveness and Application Quality. International Journal of Selection and Assessment, 8, 76-84. https://doi.org/10.1111/1468-2389.00135

[12] Caki, N. and Solmaz, B. (2013) The Effects of Facial Beauty in Personnel Selection: A Field Work in Retail Sector. Procedia Social and Behavioral Sciences, 84, 1203-1206. https://doi.org/10.1016/j.sbspro.2013.06.728

[13] Kulka, R.A. and Kessler, J.B. (1978) Is Justice Really Blind? The Influence of Litigant Physical Attractiveness on Judicial Judgment. Journal of Applied Social Psychology, 8, 366-381. https://doi.org/10.1111/j.1559-1816.1978.tb00790.x

[14] Shtudiner, Z. and Klein, G. (2019) The Impact of Gender and Attractiveness on Judgment of Accountants' Misbehaviors. https://ssrn.com/abstract=3391257 https://doi.org/10.2139/ssrn.3391257

[15] Eagly, A.H., Ashmore, R.D., Makhijani, M.G. and Longo, L.C. (1991) What Is Beautiful Is Good, But...: A Meta-Analytic Review of Research on the Physical Attractiveness Stereotype. Psychological Bulletin, 110, 109-128. https://doi.org/10.1037/0033-2909.110.1.109

[16] Dipboye, R.L., Arvey, R.D. and Terpstra, D.E. (1977) Sex and Physical Attractiveness of Raters and Applicants as Determinants of Resume Evaluations. Journal of Applied Psychology, 62, 288-294. https://doi.org/10.1037/0021-9010.62.3.288 
[17] Hamermesh, D.S, and Biddle, J.E. (1994) Beauty and the Labor Market. The American Economic Review, 84, 1174. https://doi.org/10.3386/w4518

[18] Ruffle, B. and Shtudiner, Z. (2015) Are Good-Looking People More Employable? Management Science, 61, 1760-1776. https://doi.org/10.1287/mnsc.2014.1927

[19] Pallett, P.M., Link, S. and Lee, K. (2010) New “Golden” Ratios for Facial Beauty. Vision Research, 50, 149-154. https://doi.org/10.1016/j.visres.2009.11.003

[20] Klein, G. and Shtudiner, Z. (2018) Judging Ethical Behavior in the Workplace: The Role of Attractiveness and Gender. https://ssrn.com/abstract=3122277 https://doi.org/10.2139/ssrn.3122277

[21] Morrow, P.C. (1990) Physical Attractiveness and Selection Decision Making. Journal of Management, 16, 45-60. https://doi.org/10.1177/014920639001600104

[22] Reingen, P.H. and Kernan, J.B. (1993) Social Perception and Interpersonal Influence: Some Consequences of the Physical Attractiveness Stereotype in a Personal Selling Setting. Journal of Consumer Psychology, 2, 25-28. https://doi.org/10.1016/S1057-7408(08)80073-3

[23] DeShields, O.W., Kara, A. and Kaynak, E. (1996) Source Effects in Purchase Decisions: The Impact of Physical Attractiveness and Accent of Salesperson. International Journal of Research in Marketing, 13, 89-101. https://doi.org/10.1016/0167-8116(95)00036-4

[24] Debevec, K., Madden, T.J. and Kernan, J.B. (1986) Physical Attractiveness Message Evaluation, and Compliance: A Structural Examination. Psychological Reports, 58, 503-508. https://doi.org/10.2466/pr0.1986.58.2.503

[25] Horai, J., Naccari, N. and Fatoullah, E. (1974) The Effects of Expertise and Physical Attractiveness upon Opinion Agreement and Liking. Sociometry, 37, 601-606. https://doi.org/10.2307/2786431

[26] Chaiken, S. (1979) Communicator Physical Attractiveness and Persuasion. Journal of Personality and Social Psychology, 37, 1387-1397. https://doi.org/10.1037/0022-3514.37.8.1387

[27] Kahle, L.R. and Homer, P.M. (1985) Physical Attractiveness of the Celebrity Endorser: A Social Adaptation Perspective. Journal of Consumer Research, 11, 954-961. https://doi.org/10.1086/209029

[28] Caballero, M.J., Lumpkin, J.R. and Madden, C.S. (1989) Using Physical Attractiveness as an Advertising Tool: An Empirical Test of the Attraction Phenomenon. Journal of Advertising Research, 29, 16-22.

[29] Baker, M.J. and Churchill Jr., G.A. (1977) The Impact of Physically Attractive Models on Advertising Evaluations. Journal of Marketing research, 14, 538-555. https://doi.org/10.1177/002224377701400411

[30] Malul, M., Rosenboim, M. and Shavit, T. (2010) Costs of Mistrust between Ethnic Majority and Minorities: Evidence from Israel. Review of Social Economy, 68, 447-464. https://doi.org/10.1080/00346760903480541

[31] Rubinstein, Y. and Brenner, D. (2014) Pride and Prejudice: Using Ethnic-Sounding Names and Inter-Ethnic Marriages to Identify Labor Market Discrimination. The Review of Economic Studies, 81, 389-425. https://doi.org/10.1093/restud/rdt031

[32] Greene, W.H. (2012) Econometric Analysis. 7th Edition, Prentice-Hall, Upper Saddle River. 